\title{
DA HIBRIDIZAÇÃO À REGIONALIZAÇÃO: A PUBLICIDADE CONTEMPORÂNEA
}

\author{
COVALESKI, Rogério. Idiossincrasias publicitárias. Curitiba: \\ Maxi, 2013. 157 p.
}

Pablo Moreno Fernandes Viana

Pontifícia Universidade Católica de Minas Gerais, Minas Gerais, Brasil.

Professor da Pontifícia Universidade Católica de Minas Gerais. Doutorando do Programa de Pós-Graduação em Ciências da Comunicação da Escola de Comunicação e Artes da Universidade de São Paulo.

E-mail: pablomoreno@gmail.com

A obra de Rogério Covaleski, Idiossincrasias publicitárias, traça um panorama da publicidade contemporânea a partir de dois caminhos: um primeiro a partir de suas hibridizações; e outro em virtude de sua mudança de Curitiba para Recife - para atuar na Universidade Federal de Pernambuco (UFPE) -, que gerou motivações para estudos, a partir do olhar estrangeiro.

Apoiado na relação entre persuasão, entretenimento e interatividade, o autor recorre à retórica aristotélica - aplicada ao processo de criação para problematizar o texto publicitário, fundamentado em Carrascoza e Lipovetsky. A publicidade em hibridização mistura-se com o conteúdo para ser compreendida como entretenimento e complexifica o processo criativo. Para atender às demandas do público, ela passa a ser composta por quatro dimensões: persuasão, entretenimento, interação e compartilhamento. Nessa nova ordem, cabe ao profissional compreender cada vez mais o sujeito, suas necessidades e a lógica do consumo.

Dando sequência às transformações da publicidade, debruça-se sobre outras interfaces. Reflexões sobre a tecnologia em torno da publicidade visa pensar num "possível adjacente" entre comunicação e tecnologia. Covaleski apresenta o conceito de comunicação por conteúdo (branded content) como forma bem aceita pelo público por ser menos invasiva: “o entretenimento de marca será criado com base no que realmente importa aos consumidores, no que de fato cativará sua atenção, sua razão, sua sensibilidade” (p. 41). Nessa lógica, cabe às marcas estabelecerem pontos de contato com os consumidores. Tais pontos estão presentes nos diversos campos de expressividade da marca em Perez, cada vez mais ampliados nesse contexto de ubiquidade.

Covaleski problematiza também as relações entre a comunicação e a arte, partindo do conceito de estética, segundo Baumgarten, Kant e uma nova estética, de acordo com Santaella. O autor relaciona as expressões artísticas com o marketing e a publicidade, como assinala Canclini. Tais hibridizações têm originado produtos com linguagens cada vez mais convergentes e imagens cada vez mais híbridas.

1. Expressão cunhada por Stuart Kauffman, que, segundo Covaleski, corresponde ao "conjunto de combinações que, rearranjadas, passam a ter novas funções e aplicações, os diálogos entre comunicação e tecnologia ditam boa parte das inovações que visam à interação entre públicos” (p. 37). 
Também são discutidas obras artístico-comunicativas, debruçando-se sobre as confluências entre produtos midiáticos da cultura de massa com a comunicação publicitária. Partindo das condições que o entretenimento engloba, apresentadas por Cunha - a saber: experiências, linguagens e indústria -, o autor o vê como um "produto midiático destinado a sorver de ludicidade os momentos vagos e de contemplação dos indivíduos” (p. 69).

Covaleski menciona outras manifestações artísticas que se apropriaram de signos do universo do consumo, como a pop-art, por exemplo; além do cineasta soviético Dziga Vertov, que constrói um retrato da sociedade em processo de industrialização. Numa provocação a Adorno e Horkheimer, o autor menciona o projeto Coleção de Arte Renault. A montadora de veículos fez nascer uma forma de expressão híbrida entre a arte e a indústria, disponibilizando apoio financeiro, técnico e tecnológico para que artistas criassem obras a partir desse universo.

Ele coloca a dificuldade em conceituar a linguagem publicitária, em virtude de sua hibridização. Após ampla discussão, ele conclui que é possível compreender a publicidade contemporânea como híbrida, em transformação, e rumo a tornar-se um produto midiático. Para ele, o mais importante é que sua linguagem seja capaz de persuadir, entreter e interagir, em razão de sua presença.

Covaleski defende que o consumo de anúncios publicitários é diferente do consumo de produtos. Dessa forma, a publicidade recorre a aspectos que retiram o foco da mensagem sobre o objeto anunciado, enfatizando cada vez mais a peça em si. Ela exerce um papel de estetização do cotidiano, constituindo uma "imagética do consumo", como coloca Rocha. A função da publicidade, nesse contexto, passa a ser expressar a condição hegemônica do consumo hedonista, na qual consumir justifica a existência e a busca pela felicidade. Dessa forma, a publicidade cumpre seu papel de fetichização das mercadorias.

Nos três capítulos que se seguem, Covaleski discute a influência de aspectos regionais na publicidade, particularmente no estado de Pernambuco.

O primeiro analisa a campanha publicitária da Globo Nordeste, criada pela agência Fishy para divulgar o Prêmio de Mídia 2011. A campanha faz referência a uma série de aspectos identitários de Pernambuco e é analisada à luz da enunciação proverbial irônica, como teoriza Maingueneau. Ele recorre a Canclini e seus estudos acerca das culturas populares, resgata aspectos históricos curiosos da história pernambucana e afirma que elas "povoam o imaginário local e constituem ingredientes de uma pernambucanidade” ( $p$. 106). A análise se constrói em torno da observação do discurso da campanha publicitária, que enaltece essa "pernambucanidade", preparando o terreno para a discussão do capítulo seguinte, sobre as apropriações de elementos regionais para ampliar o engajamento em campanhas publicitárias.

Para verificar a existência de uma estética própria em campanhas veiculadas no estado de Pernambuco, o autor parte para uma busca que visa "identificar as razões pelas quais há uma veemente adequação desse texto publicitário aos elementos da linguagem regional, evidenciando e enaltecendo o sentimento de pernambucanidade” (p. 117). Covaleski se ancora nas relações dialógicas de Bakhtin, nos recursos de estilização do texto de Maingueneau e remonta aos hibridismos entre a publicidade e a arte discutidos.

Esse percurso prepara terreno para a análise da presença do artista pernambucano Romero Britto, assim como o trabalho de outro artista 
do estado - Francisco Brennand - e da arte do cordel como estética na publicidade local. Ele cita anunciantes como o restaurante Parraxaxá e a Feira Nacional de Negócios do Artesanato (Fenearte), que se apropriam das obras de artistas pernambucanos em sua comunicação publicitária. Até mesmo anunciantes com alcance nacional regionalizam sua comunicação em Pernambuco, como o Banco do Brasil, que utiliza o trabalho da artista plástica Joana Lira em suas campanhas. Diante disso, Covaleski associa a apropriação à recontextualização do ready-made de Marcel Duchamp apresentada por Carrascoza.

Em outro exemplo, o autor problematiza se a regionalização do discurso das marcas trata de uma questão estética, retomando as discussões iniciais da obra. Ele cita a campanha publicitária do Instituto Cervantes do Recife, que se apropriou da simbologia da bandeira pernambucana em sua expressividade da marca. O último exemplo é a aguardente Pitú, que reforça a pernambucanidade em todo seu discurso, fazendo menção a iconografias e costumes regionais.

$\mathrm{O}$ autor destaca as altas taxas de crescimento da região Nordeste, enfatizando o crescimento do ciclo de consumo. Para finalizar, apresenta um estudo de branding realizado pelo Grupo Troiano, no qual são destacados fatores que garantem o poder da marca junto aos consumidores regionais. São eles: apartheid mercadológico, segredo logístico, cultura local, confirmação da presença, belonging, preservação da identidade. Ele conclui que o levantamento realizado oferece indícios suficientes para que seja dada continuidade à investigação, "pois em poucos estados brasileiros nota-se um diálogo tão intenso entre as expressões artísticas da cultura regional e o discurso publicitário que as legitima” (p. 129).

O último capítulo verifica as apropriações, por meio da publicidade pernambucana, dos personagens do principal evento do estado: o Carnaval de Olinda e do Recife. Tal apropriação contribui para as marcas, naturalmente, mas também contribui para constituir os seres apropriados como míticos. A fundamentação teórica ancora-se em textos da antropologia, história, comunicação, filosofia, sociologia e semiótica. Ele problematiza o Carnaval como fenômeno social, antropológico e comunicativo e, diante da magnitude do evento, conclui ser improvável não associar marcas ao evento. Covaleski analisa a apropriação de ícones do Carnaval de Pernambuco pelas marcas, particularmente o Caboclo de Lança, o Galo da Madrugada e a Passista do Frevo. O encerramento do texto indica futuros desdobramentos em torno da análise, mas já solidifica a presença das três personagens recortadas como elementos frequentemente ressignificados pela publicidade pernambucana.

A obra de Covaleski tem importância capital para os estudos sobre consumo no Brasil, por tratarem de um tema extremamente contemporâneo. Como o próprio autor coloca, a publicidade vive um período de hibridização e transformação em sua linguagem e em seus modos de fazer. Ela se sofistica enquanto produto midiático e passa a ser consumida como um produto pelo espectador. Por essa razão, justifica-se a leitura da obra para estudiosos, pesquisadores e profissionais do mercado.

Além da reflexão teórica, a obra olha para a publicidade pernambucana sob o ponto de vista do estrangeiro. Covaleski, ao fixar residência na região, passou a observar, como pesquisador, a publicidade local e apontou temas que são discutidos na obra que sinalizam para objetos de estudo a serem explorados num contexto no qual o global passa, cada vez mais, a olhar para aspectos locais. 